\title{
The Role of Teachers in The Formation of Character Value of Basic School Students Based on Pancasila in Digital 4.0
}

\section{Dian Candra Wati, Hana Zafirotul Khusna, Fildzah Kholishotul Azizah}

Universitas Sebelas Maret

diancandra027@gmail.com

\section{Article History}

accepted 24/09/2019

approved 01/10/2019

published 01/12/2019

\begin{abstract}
This article aims to identify the importance of the teacher's role in shaping the values of Pancasila-based elementary school children in the digital age. The method used in the form of literature study by conducting a review of the literature, books, and reports relating to the case to be solved. Pancasila reflects the value of character which has an important role in character building. The role of the teacher in shaping the character of elementary school students, among others, is strengthening the foundation of faith, accustoming to good behavior, instilling values of unity, tolerance, tolerance, and being honest, moral, and responsible.
\end{abstract}

Keywords: Character, Pancasila, Teacher's Role.

\section{Abstrak}

Artikel ini bertujuan mengidentifikasi pentingnya peran guru membentuk nilai karakter anak sekolah dasar berbasis Pancasila di era digital. Metode yang digunakan berupa studi kepustakaan dengan melakukan penelaahan terhadap literatur-literatur, buku-buku, dan laporan-laporan yang berhubungan dengan kasus yang akan dipecahkan. Pancasila mencerminkan nilai karakter yang mempunyai peran penting dalam pembentukan karakter. Peran guru dalam pembentukan karakter siswa sekolah dasar antara lain memperkuat dasar keimanan, membiasakan untuk berperilaku baik, menanamkan nilai persatuan, toleransi, tenggang rasa, dan bersikap jujur, bermoral, serta bertanggung jawab.

Kata kunci: Karakter, Pancasila, Peran Guru.

Social, Humanities, and Education Studies (SHEs): Conference Series https://jurnal.uns.ac.id/shes 


\section{PENDAHULUAN}

Dewasa ini, perkembangan teknologi menuntut pendidik khususnya guru Sekolah Dasar untuk bisa menyikapi perubahan teknologi yang semakin modern. Indonesia saat ini telah memasuki era 4.0 (era digital). Perkembangan pendidikan di era ini sangat cepat. Kemajuan teknologi tidak hanya dirasakan oleh orang dewasa, namun lebih dari itu anak-anak sekolah dasar juga sudah dapat mengakses berbagai informasi dengan gampang.

Permasalahan yang berkembang saat ini di masyarakat dan di sekolah banyak anak yang mengalami degradasi nilai karakter diantara pesatnya kemajuan teknologi. Seperti halnya kehidupan yang sekarang, berbagai informasi begitu mudah diakses dengan teknologi. Selama ini banyak anak bebas mempergunakan internet dalam dunia teknologi, salah satunya mengunggah gambar yang tidak pantas terhadap etika dan norma yang berlaku di masyarakat. Rasa malu dalam jiwa anak sudah tergerus sehingga anak-anak sesuka hati bertindak sesuai keinginan mereka melalui teknologi. Beberapa perilaku lain peserta didik yang menunjukkan merosotnya karakter anak yang bersimpangan dengan kandungan nilai Pancasila di antaranya mencontek, membolos, gamer, membully sesama teman dan lain-lain. Kondisi ini hanya bagian terkecil saja, hal demikian tentu tidak bisa diacuhkan, lebih-lebih peserta didik usia sekolah dasar merupakan penyambung kehidupan bangsa. Salah satu upaya yang perlu kita lakukan yaitu menanamkan nilai karakter bangsa Indonesia kembali sejak kecil terutama untuk anak-anak sekolah dasar.

Pendidikan nilai karakter, menurut Citra (2012), "suatu sistem penanaman nilainilai karakter kepada warga sekolah yang meliputi komponen pengetahuan, kesadaran atau kemauan, dan tindakan untuk melaksanakan nilai-nilai tersebut baik terhadap Tuhan Yang Maha Esa (YME), diri sendiri, sesama, lingkungan, maupun kebangsaan sehingga menjadi manusia insan kamil." Keberlangsungan negara Indonesia di zaman digital, menuntut kita sebagai Warga Negara untuk membudayakan nilai-nilai Pancasila, agar penerus bangsa bisa menghayati dan mengamalkannya serta menjaga kandungan nilai luhur supaya tetap terjaga dan menjadi petunjuk hidup bangsa Indonesia (Asmaroini, 2017). Pancasila adalah suatu ideologi atau pandangan hidup yang menjadi landasan dalam mengambil segala keputusan dimana di dalamnya terdapat nilai-nilai karakter yang mencerminkan kepribadian bangsa Indonesia. Selaras dengan pendapat Asmaroini, Azizan dan Maulana (2018), juga menyatakan bahwa pendidikan nilai karakter berbasis Pancasila harus ditumbuhkan pada peserta didik sejak memasuki bangku sekolah dasar. Hal tersebut dikarenakan pada tahap ini peserta didik sangat mudah merespon dan meniru apa yang mereka lihat secara real. Pada lingkungan sekolah guru secara tidak langsung dijadikan sebagai suri tauladan peserta didik.

Guru adalah seorang pendidik profesional yang berperan dalam mendidik serta membentuk karakter siswa supaya menjadi manusia yang berkarakter sesuai dengan nilai Pancasila. Agar pendidikan nilai karakter bisa terbentuk dengan pas maka dibutuhkan guru yang berkarakter, karena pendidik yang berkarakter dapat membentuk siswa yang tidak hanya tahu nilai karakter, namun juga diharapkan peserta didik bisa mengamalkan nilaii karakter berlandaskan Pancasila sejak kecil dalam berinteraksi dengan masyarakat sekitar. Oleh karena itu, di era digital 4.0 ini dibutuhkan peran guru yang tidak hanya mengenalkan nilai-nilai karakter yang berlandaskan nilai-nilai Pancasila, namun guru juga harus bisa membentuk karakter dalam diri anak supaya sesuai dengan nilai Pancasila yang merupakan cerminan diri bangsa Indonesia. Berdasarkan pemaparan tersebut, artikel ini disusun dengan tujuan untuk menelaah pentingnya peran guru dalam pembentukan nilai karakter anak sekolah dasar yang berbasis Pancasila di era digital. 


\section{METODE}

Metode yang kami digunakan yakni berupa studi kepustakaan. Menurut Nazir (2003) menyatakan bahwa "Studi kepustakaan adalah teknik pengumpulan data dengan mengadakan studi penelaahan terhadap buku-buku, literatur-literatur, catatancatatan, dan laporan-laporan yang ada hubungannya dengan masalah yang dipecahkan." Sebagai peneliti kami melakukan berbagai kajian yang erat kaitannya dengan topik penelitian dan teori yang sesuai, serta menghimpun informasi sebanyak mungkin dari berbagai kepustakaan yang berkaitan.

\section{Karakter Siswa di Era Digital 4.0}

\section{HASIL DAN PEMBAHASAN}

Menurut pendapat Setiawan, (2017: 92) karakter merupakan cara berfikir dan bertindak yang merupakan ciri khas individu untuk hidup dan bekerjasama di lingkungan keluarga dan masyarakat. Seorang individu yang memiliki karakter akan tercermin dalam kesehariannya di lingkungan tempat tinggalnya yang mampu bersosialisasi dan mengembangkan diri dengan orang-orang sekitar.

Pendidikan nilai karakter adalah usaha menanamkan kebiasaan yang sesuai sehingga anak dapat bersikap dan berperilaku sesuai dengan nilai kepribadian yang ada dalam dirinya (Kemendiknas, 2011: 6). Dalam pembangunan karakter banyak pihak yang dilibatkan antara lain keluarga, pemerintah, masyarakat sipil, satuan pendidikan, dan media massa. Pendidikan nilai karakter sendiri melibatkan 3 aspek yakni aspek pengetahuan, psikomotor, dan sikap. Dalam dunia pendidikan, hal tersebut searah dengan evaluasi di dalam kurikulum 2013.

Menurut UU No. 20 tahun 2003 tentang Sisdiknas, "pendidikan budaya dan karakter bangsa diartikan sebagai proses internalisasi serta penghayatan nilai-nilai budaya dan karakter bangsa yang dilakukan peserta didik secara aktif dibawah bimbingan guru, kepala sekolah dan tenaga kependidikan serta diwujudkan dalam kehidupannya di kelas, sekolah dan masyarakat." Pendidikan nilai karakter di Indonesia salah satunya bersumber pada Pancasila. Seiring dengan penjelasan sebelumnya, pendidikan dapat disebut berkarakter jika didalamnya mengandung nilai luhur seperti jujur, toleransi, disiplin, kreatif, mandiri, kerja keras, religius, demokratis, rasa ingin tahu, semangat kebangsaan, cinta tanah air, membaca, dan peduli sosial (Kementerian Pendidikan Nasional, 2010).

Industri 4.0 atau era digital merupakan era meningkatnya pemakaian teknologi di berbagai cabang bidang seperti android, dan IOs. Pada bidang pendidikan, perubahan revolusi digital memiliki banyak tantangan khususnya untuk sekolah dasar. Revolusi digital 4.0 dapat disebut sebagai tantangan apabila teknologi disalahgunakan oleh anak.

Di era digital ini, anak banyak dimanjakan dengan teknologi yang serba cepat dan praktis, misalkan dalam mengakses materi pembelajaran dengan memanfaatkan situs internet. Adapun ciri-ciri pengguna digital yang akrab disapa dengan "Generasi Digital" antara lain: (a) banyak pengguna membuat akun di berbagai media sosial, (b) pengguna cenderung bersikap terbuka dan agresif dalam bertindak serta berfikir, (c) pengguna cenderung ingin mendapat kebebasan yang berlebihan saat bergaul dengan sesama, dan (d) generasi digital selalu mengakses situs pencarian untuk mendapatkan segala informasi.

Dalam kehidupan nyata, anak sekolah dasar di digital kini kerap menyalahgunakan kemajuan teknologi seperti mengunggah kalimat, gambar, serta video tidak pantas untuk dikonsumsi anak usia sekolah. Semakin banyaknya penyalahgunaan teknologi yang dilakukan peserta didik menunjukkan semakin tingginya tingkat degradasi etika dan penyimpangan nilai-nilai Pancasila. 


\section{Nilai-Nilai Pancasila}

Menurut Djahiri (Azizan, 2017: 292) nilai adalah seperangkat ide atau gagasan, dan sesuatu yang bermakna berdasarkan standar logika pikiran, etika, keindahan, hokum, dan religius yang menjadi pandangan motivasi untuk bersikap dan bertindak serta dijadikan standar guna mengukur suatu kegiatan.

Pancasila merupakan suatu orientasi hidup, falsafah, dan Dasar Negara yang memiliki kandungan nilai luhur mendalam yang diwujudkan dalam berkehidupan bermasyarakat (Setiawan, 2017: 76). Pancasila di Indonesia merupakan suatu hal yang tidak asing, dimana isi Pancasila telah tertuang dalam UUD 1945. Pancasila tidak hanya sekedar dihafalkan, lebih dari itu nilai Pancasila harus bisa diterapkan di lingkungan bermasyarakat. Nilai dasar yang berada dalam Pancasila terdiri dari nilai ketuhanan, kemanusiaan, persatuan, dan kerakyatan, serta nilai keadilan.

\section{Peran Guru dalam Penanaman Nilai Karakter Berbasis Pancasila}

Guru merupakan seorang pendidik yang profesional dimana mempunyai tuags untuk mendidik, melatih, menilai, membimbing, mengajar, mengarahkan, dan mengevaluasi siswa dalam melewati pendidikan. Menurut UU No 14 Tahun 2005 yang berisi tentang Guru dan Dosen, guru yang profesional harus menguasai 4 kompetensi yaitu:

a. Kompetensi Pedagogik

Merupakan kemampuan untuk memahami siswa, perancangan dan pelaksanaan pembelajaran, penilaian proses dan hasil belajar, serta mengembangkan berbagai potensi yang dimiliki oleh siswa.

b. Kompetensi Profesional

Merupakan kepiawaian seorang pendidik dalam menguasai materi-materi pembelajaran secara luas dan mendalam.

c. Kompetensi Kepribadian

Merupakan kemampuan individu yang mencerminkan diri yang mantap, berakhlak mulia, dan berwibawa sebagai panutan siswa.

d. Kompetensi Sosial

Merupakan kecakapan yang dimiliki pendidik dalam berkomunikasi serta berinteraksi dengan orang disekitarnya.

Namun dalam perkembangannya, guru yang memiliki empat kompetensi seperti di atas belum sepenuhnya dikatakan profesional karena pada era digital ini guru harus mampu menguasai teknologi guna mendukung proses pembelajaran. Guru yang mengamalkan nilai karakter akan terlihat penyayang, mudah tersenyum, baik hati, dan berjiwa pemaaf. Pendidik yang berjiwa karakter kuat tidak sekedar mentransfer pengetahuan, namun pendidik harus bisa mendidik sekaligus dapat memotivasi siswanya agar kelak menjadi manusia yang jujur, bertanggungjawab, serta santun dalam bertindak.

Menurut pendapat Leonardy Harmainy (Wibowo, 2012), pendidikan karakter hendaknya dimulai sejak anak berada difase usia dini. Anak usia sekolah dasar mempunyai peran vital dalam pertumbuhan dan perkembangan kecerdasan anak, sehingga diharapkan pendidik bisa memanfaatkan peluang tersebut dalam menanamkan nilai karakter pada anak. Hal itu selaras dengan pendapat Muhammad (Santoso, 2017), pendidikan nilai moral hendaknya ditumbuhkan saat anak berada dalam tingkat perkembangan moral yakni pada usia 5-17 tahun. Pada fase usia tersebut anak membutuhkan orang lain untuk mengayomi mereka, sehingga diharapkan guru bisa mananamkan karakter saat kegiatan pembelajaran.

Pada era digital, perubahan IPTEK semakin berkembang. Proses pembentukan karakter anak seharusnya dilakukan oleh orang tua. Tetapi, saat anak berada di lingkungan sekolah, tugas orang tua digantikan pendidik. Pendidik diharuskan bersungguh-sungguh dalam menjalankan tugasnya, apabila pendidik salah dalam 
membentuk dan menanamkan karakter anak dapat berdampak fatal terhadap kehidupan anak. Pendidikan Pancasila bisa dimanfaatkan sebagai media dalam membentuk karakter anak, karena Pancasila mengandung nilai kehidupan yang dapat dijadikan prinsip dalam menjalankan kehidupan. Oleh karena itu, diharapkan anak mempunyai karakter yang sesuai dengan nilai Pancasila sehingga kelak akan lahir generasi penerus bangsa yang berakal dan bermoral. Berikut hal-hal yang perlu dilakukan pendidik dalam pembentukan karakter anak berdasarkan kandungan nilai Pancasila, seperti berikut:

a. Pendidik senantiasa berperilaku baik dihadapan siswa sehingga anak secara tidak sadar akan mencontoh apa yang ia lihat.

b. Pendidik selalu mewajibkan anak didiknya untuk melaksanakan ibadah sesuai dengan kepercayaannya.

c. Pendidik membiasakan anak didiknya untuk berinteraksi dengan semua temannya tanpa memandang agama, latar belakang pendidikan orangtua, ataupun suku.

d. Pendidik membiasakan anak didiknya untuk mengambil keputusan dengan mufakat/ bermusyawarah bersama.

\section{SIMPULAN}

Perkembangan teknologi tingkat 4.0 atau yang biasa disebut era digital menyebabkan kemerosotan karakter pada peserta didik. Kandungan nilai Pancasila yang mencerminkan tabiat penduduk Indonesia sudah mulai terdegredasi. Oleh karena itu, dibutuhkan peran nyata pendidik dalam membentuk karakter siswa sekolah dasar. Pada era ini, guru profesional tidak cukup memiliki 4 kompetensi seperti yang telah dijabarkan sebelumnya, namun pendidik perlu menguasai teknologi yang saat ini sedang berkembang.

Pada proses membentuk karakter anak, pendidik bisa berpatok dengan Pancasila karena Pancasila mengandung nilai karakter yang harus diamalkan peserta didik dalam kehidupannya. Merosotnya karakter peserta didik tidak boleh dibiarkan berlarut-larut. Guru sebagai orangtua kedua peserta didik harus melaksanakan perannya dalam membentuk karakter peserta didik dengan upaya diantaranya: (a) Pendidik senantiasa berperilaku baik dihadapan siswa, (b) selalu mewajibkan anak didiknya untuk melaksanakan ibadah sesuai dengan kepercayaannya, (c) membiasakan anak didiknya untuk berinteraksi dengan semua temannya, dan (d) membiasakan anak didiknya untuk mengambil keputusan dengan mufakat/ bermusyawarah bersama.

\section{DAFTAR PUSTAKA}

Asmaroini dan Puji Ambiro. (2017). Menjaga Eksistensi Pancasila Dan Penerapannya Bagi Masyarakat Di Era Globalisasi. Jurnal Pancasila dan Kewarganegaraan, Vol. 1 No. 2 Januari 2017.

Azizan dan Maulana. (2018). Pengembangan Karakter Siswa Sekolah Dasar Berbasis Pancasila di Era Revolui Industri 4.0. Prosiding Seminar Nasional Fakultas IImu Sosial Universitas Negeri Medan Vol 2 Tahun 2018, Hal 585.

Azizan, dan Nashran. (2017). "Penguatan Nilai-nilai Pancasila Pada Peserta Didik di Sekolah Dasar". Makalah disampaikan pada Seminar Nasional Tahunan Fakultas IImu Sosial dengan tema "Pendidikan Ilmu-ilmu Sosial Berwawasan Kebangsaan. Medan: Hotel Arya Duta Medan 20 Oktober 2017.

Citra, Y. (2012). Pelaksanaan Pendidikan Karakter dalam Pembelajaran. Jurnal IImiah Pendidikan Khusus. Vol 1 No 1 Januari 2012.

Kemendiknas. (2011). Panduan Pendidikan Karakter. Jakarta: Pusat Kurikulum dan Kebukuan Kemendiknas.

Kementerian Pendidikan Nasional Badan Penelitian dan Pengembangan Pusat Kurikulum. (2010). Bahan Pelatihan: Penguatan Metodologi Pembelajaran 
Berdasarkan Nilai-Nilai Budaya Untuk Membentuk Daya Saing dan Karakter Bangsa. Jakarta: Hotel Mercurel Ancol.

Nazir, Muhammad. (2003). Metode Penelitian. Jakarta: Ghalia Indonesia.

Putri, D.P. (2018). Pendidikan Karakter Pada Anak Sekolah Dasar di Era Digital. Jurnal Pendidikan Dasar. Curup: Institut Agama Islam Negeri (IAIN) Curup. Vol 2 No 1 2018.

Santoso. (2017). Penanaman Nilai-Nilai Karakter Pada Siswa Sd Pada Era Globalisasi. Prosiding Seminar Nasional 15 Maret 2017.

Setiawan, D. (2017). Pendidikan Kewarganegaraan. Medan: Madenatera.

Undang-Undang Nomor 14 Tahun 2005 Tentang Guru dan Dosen. Jakarta: Pemerintah Republik Indonesia.

Undang-undang Republik Indonesia Nomor 20 Tahun 2003 tentang Sistem Pendidikan Nasional. Jakarta: Pemerintah Republik Indonesia.

Wibowo, A. (2012). Pendidikan Karakter Usia Dini (Strategi Membangun Karakter di Usia Emas). Yogyakarta: Pustaka Pelajar. 